\title{
Exploring Use of Media Content Analysis in Competitive Dynamics Studies
}

Review paper _ UDK 316.773.3/4:65.012.12 _ Received on 01 April 2016

\section{Darko Tipurić}

Faculty of Economics and Business, University of Zagreb, Trg. J. F. Kennedya 6, Zagreb, Croatia.

Email: dtipuric@efzg.hr (corresponding author)

\section{Radoslav Barišić}

Ministry of Regional Development and EU Funds, Račkoga 6, Zagreb, Croatia.

Email: radoslav.barisic@gmail.com

\section{Abstract}

Media content analysis is commonly used as a tool for data collection in competitive dynamics research. Competitive dynamics give a comprehensive longitudinal view on competitive moves and responses effects which are measured through various models that bring insight on the consequences on performance of observed firms. Research in competitive dynamics deeply reveals competitive behavior of firms, focusing not only on the competitive moves of one competitor but also on detailed interaction of all of them in their "market battle". The prerequisite for the research is undoubtedly the high-quality data sources and well-designed data analysis. Presented in the paper were a number of issues we faced during the conduct of our recent study in which 2,699 media reports on competitive moves were collected in seventeen firm dyads in Croatia.

Keywords: competitive dynamics, media content, structured content analysis, competitive moves 


\section{Introduction}

The area of competitive dynamics focuses on the analysis of undertaken competitive moves and competitive response of the firms. Firms are making the competitive moves in order to maximize their profits, improve their competitive advantage or retain their market position if satisfied by the current situation. Research on competitive dynamics reveals how undertaken competitive moves affect the competitors, their competitive advantage and achieved performances (Smith, Ferrier, Ndofor, 2001). Competitive dynamics examines the interaction among competitors, focusing not only on competitive moves taken by one firm, but also on responses (or countermoves) by other competitors (Chen, Miller, 2012, p. 3). Research in this area provides valuable data and findings explaining the behavior of firms in the market competition with their direct competitors.

It can be stated that the collection of data and identification of competitive moves is a major challenge for authors conducting research in the competitive dynamics field (Chen, Smith, Grimm, 1992). In order to actively follow the competitive interaction between the competitors in the focus of these types of studies, all competitive moves that form a particular competition repertoire have to be recorded and systematized.

In this process it is particularly important to conduct a systematic and comprehensive analysis of media content. Without this, it is almost impossible to implement empirical research in the field of competitive dynamics. For the creation of a database on the competitive behavior of selected firms, data has to be collected from various sources in a relevant, consistent and comprehensive manner. Retrieval of such data is mainly carried out by structured content analysis of media content since this approach emphasizes the competitive move as a fundamental element of analysis (Smith et al., 1992; Young et al., 1996; Ferrier et al., 1999) and it immediately initiates the necessity of collection, sorting and analysis of all important and objective data on the taken competitive moves. Therefore, particular attention is placed on the reliability and consistency of data sources, proper and accurate identification and categorization of moves and their suitability for further processing in conducting empirical research. In this paper, we present the use of media content analysis by exploring 17 dyads across several Croatian industries. 


\section{Competitive dynamics}

Competitive dynamics is defined as a series of competing moves and responses of competitors. Firms behave varied, depending on the possibilities, habits, characteristics of management, tradition etc., all in order to maintain market position, gain competitive advantage and ultimately achieve good performance. Successfully implemented moves cause competitive responses and encourage competitors to become more agile, aiming to neutralize competitors' strategy.

\subsection{Main research model}

The research model of competitive dynamics reveals that undertaken competitive moves of one firm affect the competitive advantage and business success of the competitors. The escalation of mutual attacks between the firms can result in reduction of industrial profitability and therefore firms need to be especially thoughtful when choosing a strategy of market performance (Smith, Ferrier, Ndofor, 2001, p. 3).

Scholars in the field of competitive dynamics pay special attention to the analysis of competitors' interactions through visible competitive moves and effects of competitive activity on the achievement of business performance (Chen, 1992, 1994; Young, Smith, Grimm, 1996; Ferrier, 1999, 2001). The interest of scholars is focused on how individual competitor moves affect the possibility and speed of competitor response and how performance and market position rely on competitive moves, characteristics and strategic interaction of firms (Tipurić, 2014).

The fundamental connection is the one between performance and competitive dynamics, attributes like aggressiveness, persistence, timing and speed in competitive behavior (Chen, MacMillan, 1992; Ferrier, 2001). The main relations are among market leaders, their competitor(s), and competitive moves and responses they undertake in mutual interaction. 


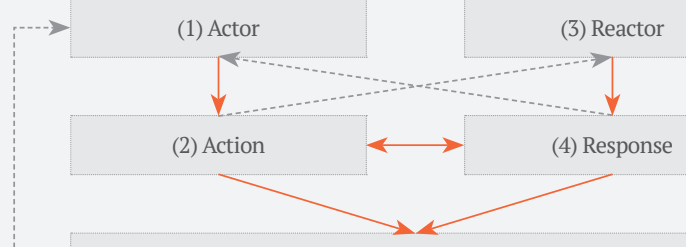

(6) Organisational performance

Figure 1: Base model of competitive dynamics

Source: Albers, S., Heuermann, C. (2013). Competitive Dynamics across Industries: An Analysis of Inter-Industry Competition in German Passenger Transportation. Schmalenbach Business Review, 65, p. 434.

Figure 1 provides an overview of the model of competitive dynamics and related relations and components such as: actor (firm undertaken by competitive moves), action (type and strength of the effect of a particular move), reactor (firm that reacts and responds) and response (i.e. response to undertake competitive move). The last two components include industry competitive environment and achieved organizational performance as a result of competitive interactions.

Actor is the firm which initiates competitive activity and first takes competitive moves. In competitive dynamics studies, the actor is an important factor since it is the initiator of competitive behavior and consequently the subject which obtains the results of the impact of undertaken competitive moves. An important segment of competitive dynamics research focuses on the impact the actor has in relation to the characteristics and effects of competitive moves that firms implement within their business strategies. It is considered that each firm has specific abilities and follows idiosyncratic rules of governance and decision-making. If we consider the firm as a repository of skills and routines, then it is precisely these abilities and routines which determine the results of the firm. Over time, these abilities and rules change as a result of a deliberately and consciously invested effort, but also as a result of 
chance. Market mechanisms determine the measure of success of these firms and tend to eliminate those firms that are unprofitable and unprepared for market competition in favor of those well-prepared, which achieve good results (Nelson, Winter, 1982).

Most of the studies focused on competitive moves (actions) are based on the Austrian school which considers competitive moves the crucial drivers of market processes. The competitive move can be defined as an externally focused, specific and visible action initiated by a firm in order to improve its relative competitive position (Chen et al., 1992, p. 440; Ferrier et al., 1999, p. 373). According to Israel M. Kirzner (1973), firms realize and defend their competitive advantage by positioning themselves in relation to their competitors and by creating new, innovative ways of market behavior while finding opportunities to realize additional advantages over competitors. Considering these theoretical assumptions, competitive dynamics research postulates firm strategy being actually made of competitive actions which position the firm in the competitive environment.

Firms on the one hand can be initiators of competing moves, but on the other hand can be in the role of reactor corresponding to already undertaken moves of others. The firms that respond to the moves of others can have all the organizational characteristics and features that the firm which initially undertook a competitive move has (e.g. firm size, demographic characteristics of top management team, etc.).

Response is defined as a clear, visible reaction, or countermove taken by another firm (or a few of them) with the objective of preserving or enhancing its position (Porter, 1980). Scholars have discovered a possible way of monitoring the responses of competitors in a particular market. A number of studies were used to analyze some of the characteristics of the competitors' responses. So, some of them measured the likelihood of response, response type, time period of competitive moves undertaken to reaction and the order of response (Smith et al., 1991), while other authors developed measures such as recognition of significant responses, response range and speed of generating responses (Chen, Hambrick, 1995, pp. 454-458). When competitors choose to respond to an undertaken competitive move, they have more options when choosing the type of approach and response characteristics (Chen, MacMillan, 1992, p. 541). 


\subsection{Main topic and themes}

Information processing perspective in the analysis of competitive dynamics provides a useful framework for understanding the behavior of direct competitors (Smith, Grimm, Gannon, 1992, p. 63). Every competitive move contains a particular message, regardless of whether we are considering the sense of a specific move or the signaling of the general strategic competitor behavior. From a research perspective, the key source of data for analysis of the relationship in competitive dyad "actor-reactor" is media reports that affect competitive moves.

The range (specter) of moves that firms implement in order to achieve a competitive advantage over other firms is called competitive repertoire. It represents a range of competitive moves undertaken during a specific period enabling the firm to attract, serve and retain customers (Miller, Chen, 1996, p. 419).

Depending on its preferences, experience, management beliefs, available stock of resources, etc., some firms implement a complex repertoire of competitive moves, and some have an opposite approach, depending on the estimated market situation, with the aim of improving the competitive position and performance (Miller, Chen, 1996, p. 424). Some researchers claim that a simple competitive repertoire can have a positive effect on the firm because it then focuses on particular activities which are estimated as the most important and accordingly allocate funds specifically to these activities. However, this approach is generally possible only in unchanging market conditions, which today is almost non-existent, given the growing competition in all business arenas, which in turn prevents firms from focusing only on those activities that bring the highest returns, due to the threat of being subdued by competitors in all other areas (Miller, Chen, 1996).

Firms that undertake a complex repertoire of competitive moves are considered more aggressive and better equipped for the competition. Their moves are seen as less predictable and therefore it is more difficult to respond to them during possible competitive activities (D'Aveni, 1994). A complex repertoire of competitive moves can have a major impact on the ability of firms to adapt to the market threats and challenges (Miller, Chen, 1996, p. 425).

A well-designed competitive repertoire is an important prerequisite in firms' operations and 
in achievement of business plans. The complexity and specificity of the moves are essential in prevention of rival's fast reaction and response within the competitive interactions (Porter, 1980).

Many factors shape the competitive repertoire and the diversity of competitive moves firms take during competition. The satisfactory past financial performance may lead to inert behavior and decline in diversity of competitive moves (Miller, Chen, 1996, p. 421). In the opposite circumstances, the negative financial performance motivates firms to find alternative competitive opportunities and options (Lant, Montgomery, 1987).

Industrial growth can potentially motivate firms to undertake a variety of moves. Market conditions with increasing demand discourages competitors to make additional investments and improvements in their competitive repertoire (Miller, Chen, 1996, p. 423). The level of rivalry also determines the competitive repertoire of moves, where the rivalry and variety of moves are in proportion, or in other words, when rivalry and the competitive pressure increase, the motivation of firms for finding new options, moves increases and vice versa (Walsh, 1995).

In general, the width of competitive repertoire functions as a motivation for finding new ways of competition. Motivation for alternative actions contributes to learning, gaining experience and competence, which makes the firm even more competitive (Miller, Chen, 1996).

The research stream which examines the dynamic aspects of strategic management is focused on the relationship between competitive moves and competitive advantages (Chen et al., 1992; Bettis, Weeks, 1987; Chen, Miller, 2012). Competitive moves are the basis for competitive strategy and market positioning (Mintzberg, 1978; Porter, 1980; Thompson, Strickland, 1993). Competitive moves are defined as "specific and observable market actions and reactions taken by the firm", such as e.g. introduction of new products, marketing campaigns, pricing policy, entering new markets and the like (Chen, Miller, 2012, p. 10). These and similar competitive moves may threaten market share and other operating results of its competitors (Baum, Korn, 1999; Boyd, Bresser, 2008; Chen, Miller, 1994; Smith et al., 1992).

Ming-Jer Chen, Ken G. Smith and Curtis M. Grimm (1992) pointed out four major dimensions of competitive moves: intensity, complexity, performance and type. Walter J. Ferrier, Ken 
G. Smith and Curtis M. Grimm (1999) in turn examined several characteristics that have shaped the competitive behavior between the market leader and the main competitor and were associated with shifts in market leadership and mutual threats to the market share. The characteristics of competitive moves (such as radicalism, scope, significance, timing, irreversibility, etc.) significantly influenced characteristics of responses undertaken by competitors (probability of undertaking, response speed, etc.).

Demanding in taking particular competitive moves refers to the available resources needed for its implementation and the extent of its effect implies all concerned competitors possibly implicated by those moves. The level of the threat caused by a competitive move in relation to competitors is measured by the number of consumers potentially affected by the move (Chen, Smith, Grimm, 1992, p. 448). It is generally determined that increase of the scope and complexity of undertaken competitive moves narrows the space for competitors in their responses, but on the other hand it is argued that the increase in the firm's activities allows clearer and sooner recognition of danger and increased likelihood of competitive responses.

Other important characteristics are frequency of competitive moves and responses of other firms in certain time periods (Ferrier, Smith, Grimm, 1999, p. 67; Young, Smith, Grimm, 1996, p. 252). Studies of these concerns resulted in a conclusion that firms that made a greater number of competitive moves and were faster than other competitors had higher profitability and greater market share.

In some studies, authors also highlighted the features of an uninterrupted sequence of strategic moves undertaken in a particular time. These researches are consistent with the previous ones, in which the strategy is conceptualized as a logically unified sequential series of competitive moves (Kirzner, 1973), or as a coordinated series of competitive moves (MacCrimmon, 1993), or as a sequential collection of a large number of competitive moves (D’Aveni, 1994). Thus, in one of the studies (Ferrier, 2001), the structural dimensions of a series of strategic moves were identified and analyzed based on a number of important characteristics such as the number of competitors' moves in a certain sequence, or the average duration of uninterrupted sequence of competitive moves, followed by the extent to which all possible competitive moves are represented in a given row (i.e. complexity) of the variability within the firm representing the unpredictability and heterogeneity in a series of strategic moves that the firm carries out in a given period of time. 
The characteristics of competitive moves are important in the competitive dynamics because the overall competitive interaction and market relations depend on their type, size, performance speed taking, specifics, etc.

\section{Example of media content analysis in competitive dynamics}

In our competitive dynamics studies, we used structured content analysis as a key tool in the identification of competitive moves. Such an approach is highly suitable for testing the relative competitive activity of the market leaders and their challengers.

\subsection{Sample}

The sample in our recent survey consisted of 17 dyads (sample of 34 firms that were market leaders and their most aggressive challengers in the same market niche in different industries) in the Republic of Croatia (Barišić, 2015; Tipurić, Barišić, Arnerić, 2016). In order to define the relevant research sample, we had to select those firms that competed in industries with high competitive intensity, rich competitive interactions, respectable media coverage of competitive moves and the focus of the firm on just one particular market segment.

Competitive moves of firms (from the sample) were visible and well distributed through communication channels. In this manner, the firms were trying to gain media attention and distribute the relevant news and new actions, aiming to transfer, as much as possible, information to the targeted subjects and influential stakeholders and other interest groups (through marketing campaigns, reports, participation in community activities, etc.). On the other hand, firms from the sample attracted the attention of the media, investors, and analysts and there was a proactive approach of the media itself, which sought to convey information as accurately as possible and to inform the interested target group. This particular coverage or "visibility" was of great importance in the quality of research implementation.

The focus of interest was regularly published in media content and publications related to the operations of each firm. Data on the competitive moves were collected on the basis 
of the media reports related to each firm, published on the most visited business portals in Croatia. Portals were chosen according to the study of popularity and number of visits provided by Gemius Audience ${ }^{1}$, identified as most read Internet business portals: www. poslovni.hr, www.liderpress.hr, www.bussines.hr and two specialized portals follow particular segment: www.limun.hr and www.jatrgovac.com.

\subsection{Methodology}

All data were collected by means of daily monitoring and recording the competitive moves, containing all visible competitive activities taken by the firm in the context of their business strategies. Further processing and detailed analysis of the database was filtered and "purged" of a certain number of potentially irrelevant records, duplicates, etc.

Taking into account the best-practice experience in the study of competitive dynamics, the direct approach was implemented and structured content analysis was used as a basic tool. Structure content analysis contributed to extract relevant competitive moves taken by the firms selected from 17 dyads and collected from the media. Competitive moves were coded according to usual techniques, taking into account past experience in conducting similar types of research (Ferrier, 1999; Young et al, 1996; Smith et al., 1992).

Many authors agree that structured content analysis is a relevant method when conducting research within the field of competitive dynamics (Boyd, Bresser, 2008; Smith et al., 1991; Chen, Miller, 2012). Planned content analysis is used in this method, whereby collected relevant information is published in the media materials related to the sampled firms. This method distinguishes only specific information that is interesting and important to the researcher (Jauch et al., 1980).

The data for the empirical processing were collected by our long-term monitoring and recording of the media publications and reports during 2014 and 2015, where the media reports were detected and stored in a research database.

Categorization of moves was set in accordance with the positive experience of previous

1 Gemius Audience is a part of the largest online research agency that provides its services throughout Europe (with a focus on Central and Eastern Europe, Scandinavian countries and Western markets such as Austria) - Gemius SA. 
research, which usually stated seven to nine of the most common types of competitive moves. A broader range of moves ( 9 types) was comprised in this study, due to the differentiation of industries in which the sampled firms were competing. Therefore, the categories of moves and keywords by which the competitive moves were encoded are presented in the following table:

Table 1: Coding and categorizing the competitive moves and the keywords

Source: Adapted from Ferrier $(1999,2001)$

\begin{tabular}{|c|c|c|}
\hline $\begin{array}{l}\text { CATEGORY OF } \\
\text { COMPETITIVE MOVE }\end{array}$ & KEYWORDS & $\begin{array}{l}\text { EXAMPLES OF HEADLINES } \\
\text { FROM MEDIA RELEASES }\end{array}$ \\
\hline Pricing & $\begin{array}{l}\text { Price, rebate, } \\
\text { discount, sale... }\end{array}$ & $\begin{array}{l}\text { Huge sale on fresh } \\
\text { fruit in "Lidl" }\end{array}$ \\
\hline Marketing & $\begin{array}{l}\text { Commercial, promotion, } \\
\text { campaign... }\end{array}$ & $\begin{array}{l}\text { "Zagrebačka pivovara" } \\
\text { organize Becksperience party }\end{array}$ \\
\hline New services & $\begin{array}{l}\text { New service, online channel distribution, } \\
\text { loyalty programs, financing... }\end{array}$ & $\begin{array}{l}\text { "Konzum” now offers } \\
\text { online shopping }\end{array}$ \\
\hline New products & $\begin{array}{l}\text { New devices, extension of product range, } \\
\text { new packaging... }\end{array}$ & $\begin{array}{l}\text { New type of life } \\
\text { insurance in "Allianz" }\end{array}$ \\
\hline New capacities & $\begin{array}{l}\text { New shop, enlargement of capacity, } \\
\text { new production line... }\end{array}$ & $\begin{array}{l}\text { "Ina” starts business in } \\
\text { new petrol station in Pula }\end{array}$ \\
\hline $\begin{array}{l}\text { Mergers and } \\
\text { acquisitions }\end{array}$ & $\begin{array}{l}\text { Merger, acquisition, strategic partnership, } \\
\text { consolidation... }\end{array}$ & $\begin{array}{l}\text { "T-mobile" takes over } \\
\text { small cable operator }\end{array}$ \\
\hline Legal & Lawsuit, contest, regulatory conditions... & $\begin{array}{l}\text { "Tele2" is suing competitors } \\
\text { to the regulatory agency }\end{array}$ \\
\hline Technology & $\begin{array}{l}\text { Development of new technology, } \\
\text { building of processes, new IT solutions, } \\
\text { implementation of BI system... }\end{array}$ & $\begin{array}{l}\text { “Tisak" has implemented } \\
\text { new CRM system }\end{array}$ \\
\hline Signaling & $\begin{array}{l}\text { Intent, announcement, } \\
\text { prior information... }\end{array}$ & $\begin{array}{l}\text { "PBZ bank" has intention } \\
\text { to make special proposals } \\
\text { for big clients in next year }\end{array}$ \\
\hline
\end{tabular}

All media reports were collected daily by monitoring and recording the data available from the most-read business electronic media dealing with the observed subject. A characteristic feature of this research was the detection and in-depth processing of each competitive move unlike most previous studies where media reports basis was used, usually containing only titles and possibly a short description of the individual posts. Here, on the other hand, each publication was read and analyzed separately whereby even greater relevance and better interpretation of each publication was captured. 


\subsection{Results}

By tracking the behavior of all firms within the observed period of five years (2009-2013), a large number of media reports was collected with predefined basic content. This "raw" material contained more than 7,000 media reports, followed by the implementation of review process significance and relevance of each publication followed by the subsequent analysis (coding and subsequent elimination of certain irrelevant or incorrectly addressed media reports), which formed the database (competitive moves) encompassing all relevant media reports and depicting a concrete competitive move (2699 units).

It is important to emphasize that the collected "raw" and unrefined data also contained media duplicate reports, since the important news were regularly transmitted in all relevant media. Therefore, additional filtering and refining process had to be implemented on the collected data which resulted in elimination of twice (or repeatedly) published articles in the final data base. This one move, regardless of the multiplicity of media reports, was recorded only once, and then categorized in order to be used in further analysis.

Each press release was checked in detail several times. Firstly, during input of some posts from the electronic media into the research database, taking special care on the precision in the classification of each publication with respect to the targeted firm, including the type of competitive move and the time of its undertaking. In addition, a brief description of each competitive move and the exact source from which it was referenced was included in the research database.

In the second phase, all data collected from the research database were tested through predefined codes of all isolated competitive moves by keywords in the titles and summaries of the collected media reports. This examination helped to establish a very high correlation between the original estimate during the categorization of competitive moves and those obtained after the competitive moves had been sorted based on codes and their affiliation to a particular category.

In a small part of the competitive moves, we had a situation where some competitive moves could be classified into several categories according to the initial classification and also to the additional verification codes. In such cases, when conducting the interviews with managersexperts in the targeted firms, we sought the verification of the correct choice of category. 
Using structural content analysis was a key input in the construction of other research models that were studied (impact of competitive dynamics among competitors on firm performance, the impact of the characteristics of top management on competitive behavior, the impact of contextual factors on business policy, etc.), but these models were not the subject of this paper.

Table 2: Example for "Zagrebačka pivovara” brewery - excerpt with 3 articles on competitive moves (of the 2699 units collected and processed in total for all sample firms)

\begin{tabular}{|c|c|c|c|c|c|}
\hline FIRM & $\begin{array}{l}\text { TITLE OF } \\
\text { RELEASE }\end{array}$ & SHORT DESCRIPTION & CATEGORY & TIMING & SOURCE (LINK) \\
\hline $\begin{array}{l}\text { Zagrebačka } \\
\text { pivovara }\end{array}$ & $\begin{array}{l}\text { Niko Pulić for } \\
\text { responsible } \\
\text { driving } \\
\text { without } \\
\text { a drop of } \\
\text { alcohol }\end{array}$ & $\begin{array}{l}\text { As part of the campaign } \\
\text { "Think. When you } \\
\text { drink, do not drive", } \\
\text { Zagrebačka pivovara } \\
\text { with its educational } \\
\text { drive on Split Riva, } \\
\text { warning of the dangers } \\
\text { of drinking and driving. }\end{array}$ & Marketing & 11.7.2011 & $\begin{array}{l}\text { http://www. } \\
\text { jatrgovac. } \\
\text { com/2011/07/ } \\
\text { niko-pulic-za- } \\
\text { odgovornu- } \\
\text { voznju-bez- } \\
\text { kapi-alkohola/ }\end{array}$ \\
\hline $\begin{array}{l}\text { Zagrebačka } \\
\text { pivovara }\end{array}$ & $\begin{array}{l}\text { Ožujsko } \\
\text { Pub Tkalča } \\
\text { opening }\end{array}$ & $\begin{array}{l}\text { With the opening of } \\
\text { Zagrebačka pivovara's } \\
\text { first pub in Tkalčićeva } \\
\text { street, Zagreb receives } \\
\text { one more place for } \\
\text { pleasant meetings, } \\
\text { going out and enjoying } \\
\text { a favorite domestic beer, } \\
\text { according to the firm's } \\
\text { PR Department. }\end{array}$ & $\begin{array}{c}\text { New } \\
\text { capacity }\end{array}$ & 7.12 .2012 & $\begin{array}{l}\text { http://www. } \\
\text { jatrgovac. } \\
\text { com/2012/12/ } \\
\text { otvoren- } \\
\text { ozujsko-pub- } \\
\text { tkalca/ }\end{array}$ \\
\hline $\begin{array}{l}\text { Zagrebačka } \\
\text { pivovara }\end{array}$ & $\begin{array}{l}\text { Zagrebačka } \\
\text { pivovara } \\
\text { against crisis } \\
\text { with beer } \\
\text { Staropramen }\end{array}$ & $\begin{array}{l}\text { In a battle for } \\
\text { consumers, Zagrebačka } \\
\text { pivovara recently } \\
\text { started with the } \\
\text { licensed production } \\
\text { and distribution } \\
\text { of the Czech beer } \\
\text { Staropramen. }\end{array}$ & $\begin{array}{c}\text { New } \\
\text { products }\end{array}$ & 14.6.2010 & $\begin{array}{l}\text { http://www. } \\
\text { jatrgovac. } \\
\text { com/2010/06/ } \\
\text { zagrebacka- } \\
\text { pivovara-sa- } \\
\text { staropramenom- } \\
\text { protiv-krize/ }\end{array}$ \\
\hline
\end{tabular}

The conducted research also had some limitations mostly related to the methodological aspects of the empirical research in terms of collection and systematization of media content, due to the specificity of the approach and the small number of studies with a similar approach that could possibly help to avoid errors in the procedure and implementation of the research.

First, the integrity and relevance of "manually" collected media reports on competitive moves and afterwards applied structured content analysis were largely dependent on the focus and perseverance of the researchers. Since the number of data that was daily entered into the 
database was extremely high, some competitive moves were of questionable relevance, some were repetitions with slightly modified content, etc. Considering the above, it is possible that some of the competitive moves were inadvertently omitted (including the possibility that it was not published in the selected media source, since it was visible only to certain sources or it was internally published), which to a certain extent reduces the precision of the competitive dynamics image of the individual firm. Of course, we tried to avoid these situations as much as possible by selecting five of the most read specialized media sources that generally cover the most important news from the business world, as well as selecting the firms that were dominant in the market and as such usually provoke media attention.

In the process of competitive moves categorization, there was also the possibility that some of the competitive moves were incorrectly interpreted and categorized, considering that, in certain cases, competitive moves extracted from media reports had similar features and could be classified in several different categories and thus changed the input data for empirical use. In such cases, we requested the help of experts from specific firms who explained the meaning of each potentially controversial move, by which every competitive move was placed in the correct category, but it still failed to prevent the possibility that some small part of the competitive moves were incorrectly categorized.

A recommendation for future researchers is to take advantage of the possibility of retrieval of all relevant data on competitive moves in electronic form if the firms operating on the Croatian market actually form such databases. Such practices are used by the most prominent authors in the competitive dynamics field with the advantage of the common sample being used for research is often the US market, where such databases (like F \& S Predicast, Factiva, Aviation Daily) are available and relevant (though generally very expensive). Using this approach could significantly shorten the time required to record all competitive moves taken by the firms over a longer period of time and can eliminate the possibility of omission (by personal oversight or indifference of the media for that particular information) and therefore eliminate failure to be included in the empirical analysis. Also, the use of electronic databases will in greater extent eliminate the possibility of recording the same move multiple times, as can be the case when information on competitive moves was collected from multiple sources where it is difficult to recognize the multiply recorded move.

There is a whole specter of advantages when using specialized databases in relation to "manually collecting" and separate subsequent analysis of each media release, however, in 
cases where databases are not available, the implementation of the "manual" approach can also be very effective if conducted accurately and in accordance with instructions, and also if the researcher is provided with a sufficient amount of time.

\section{Conclusion}

The structured content analysis example of use in competitive dynamics research presented in this paper is based on many years of systematic monitoring, recording and detailed analysis of undertaken competitive moves in 17 "actor-reactor" dyads of different industries on the Croatian market. In the multiple year analysis, we collected and processed 2,699 articles (media reports) that formed a research database of competitive moves. Based on the data collected, we started analyzing the nature of competitive behavior, identification of the main drivers and analysis of decisions at the strategic and tactical level and other factors that shaped the competitive dynamics between firms.

The structured content analysis was modified and adapted to the specificities and constraints we encountered due to the lack of resources and databases on the Croatian market. In addition to structured content analysis, particularly qualitative research was conducted with in-depth interviews with experts in the analyzed industry, which contributed to better understanding and categorizing of competitive moves during the processing. Thus, we obtained information with a precise understanding of certain moves, tactical and strategic decisions, providing help in better understand the content and the meaning of competitive moves in the current structural analyses.

The use of structured content analysis of media is certainly the key in the implementation of empirical research in the field of competitive dynamics. Communication between firms is therefore a precondition for gaining access to this type of study, and the media reports represent a sort of data repository that are processed, coded, analyzed and systematized to form a proper foundation for empirical testing in research of competitive dynamics.

To conclude, we can emphasize that designing, developing and testing future research models and connections among the variables of the competitive behavior of firms in a dynamic market should be complemented with the development of techniques and methods of media content analysis. 


\section{Reference List}

- Albers, S., Heuermann, C. (2013). Competitive dynamics across industries: An Analysis of Inter-Industry Competition in German Passenger Transportation. Schmalenbach Business Review, 65, 431-453.

- Barišić, R. (2015). Dissertation: Link between competitive dynamics and firm performance. Split: Faculty of Economics.

- Baum, J. A., Korn, H. J. (1999). Dynamics of dyadic competitive interaction. Strategic Management Journal, 20 (3), 251-278.

- Bettis, R., Weeks, D. (1987). Financial returns and strategic interaction: The case of instant photography. Strategic Management Journal, 8, 7-19.

- Boyd, J. L., Bresser, R. K. F. (2008). Performance implications of delayed competitive responses: evidence from the U.S. retail industry. Strategic Management Journal, 29, 1077-1096.

- Chen, M. J., Miller, D. (1994). Competitive attack, retaliation and performance: An expectancy-valence framework. Strategic Management Journal, 15 (2), 85-102.

- Chen, M. J., MacMillan, I. (1992). Nonresponse and delayed response to competitive moves. Academy of Management Journal, 35 (3), 539-570.

- Chen, M. J., Hambrick, D. C. (1995). Speed, stealth, and selective attack: How small firms differ from large firms in competitive behavior. Academy of Management Journal, 38 (2), 453-482.

- Chen, M. J., Miller, D. (2012). Competitive dynamics: Themes, trends, and a prospective research platform. The Academy of Management Annals, 6 (1), 135-210.

- Chen, M. J., Smith, K., Grimm, C. (1992). Action characteristics as predictors of competitive responses. Management Science, 38 (3), 439-455.

- Chen, M. J., Smith, K., Grimm, C. (1992). Action characteristics as predictors of competitive responses. Management Science, 38 (3), 439-455.

- D`Aveni, R. A. (1994). Hypercompetition: Managing the Dynamics of Strategic Manoeuvring. New York: Free Press.

- Ferrier, W. J., Smith, K. G., Grimm, C. M. (1999). The Role of Competitive Action in Market Share Erosion and Industry Dethronement: A Study of Industry Leaders and Challengers. Academy of Management Journal, 42 (4), 372-388.

- Ferrier, W. J. (2001). Navigating the competitive landscape: The drivers and consequences of competitive aggressiveness. Academy of Management Journal, 44 (4), 858-877.

- Jauch, L. R., Osborn, R. N., Martin, T. N. (1980). Structured content analysis of cases: A complementary method for organizational research. Academy of Management Review, 5, 517-526.

- Kirzner, I. M. (1973). Competition and entrepreneurship. Chicago: University of Chicago Press.

- Lant, T., Montgomery, D. B. (1987). Learning from Strategic Success and Failure. Journal of Business Research, 15 (6), $503-517$.

- MacCrimmon, K. (1993). Do firm strategies exist? Strategic management Journal, 14, 113-130.

- Miller, D., Chen, M. J. (1996). The simplicity of competitive repertoires: An empirical analysis. Strategic Management Journal, 17 (6), 419-439.

- Mintzberg, H. (1978). Patterns in Strategy Formation. Management Science, 24, 934-948.

- Nelson, R., Winter, S. (1982). An Evolutionary Theory of Economic Change. Cambridge, MA: Harvard University Press.

- Porter, M. E. (1980). Competitive strategy. Boston: Harvard Business School Press.

- Smith, K. G. et al. (1991). Organizational Information Processing, Competitive Responses, and Performance in the U.S. Domestic Airline Industry. Academy of Management Journal, 34 (1), 60-85.

- Smith, K. G., Ferrier, W. J., Ndofor, H. (2001). Competitive dynamics research, critique and future directions. In: Hitt, M., Freeman, R. E., Harrison, J. (Eds.) Handbook of Strategic Management. London: Blackwell Publishers.

- Smith, K. G., Grimm, C. M., Gannon, M. J. (1992). Dynamics of competitive strategy. London: Sage Publictions.

- Thompson, A. A., Strickland, A. J. (1993). Strategic Management. McGraw-Hill Inc.

- Tipurić, D. (2014). Iluzija strategije, Zagreb: Sinergija.

- Tipurić, D., Barišić, R., Arnerić, J. (2016). The complexity of the competitive repertoire and firm performance. In: Proceedings of the 4th International OFEL Conference on Governance, Management and Entrepreneurship (pp. 530-545). Zagreb: CIRU.

- Walsh, K. (1995). Public Services and Market Mechanisms. London: Macmillan.

- Young, G., Smith, K. G., Grimm, C. (1996). “Austrian” and industrial organization perspectives on firm-level competitive activity and performance. Organization Science, 73, 243-254. 


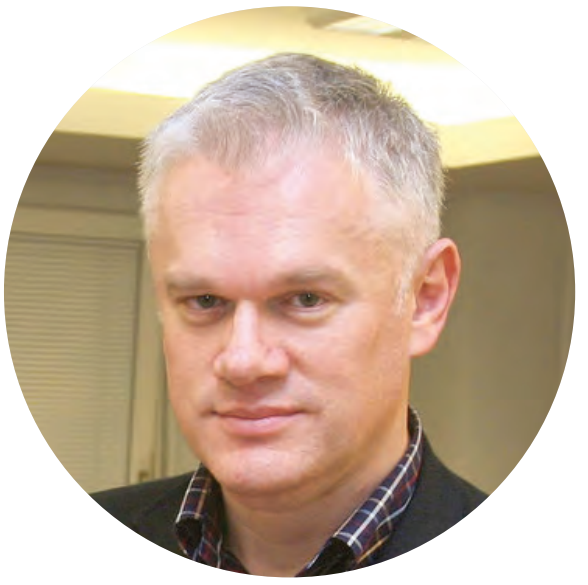

\section{Darko Tipurić}

Darko Tipurić is a Full Professor and the Head of the Department of Organization and Management, Faculty of Economics and Business, University of Zagreb. He is a Visiting Professor at the University of Malta, University of Sarajevo and University of Split. He is author and editor of fifteen books and over a hundred papers and chapters in international journals, reviews and proceedings.

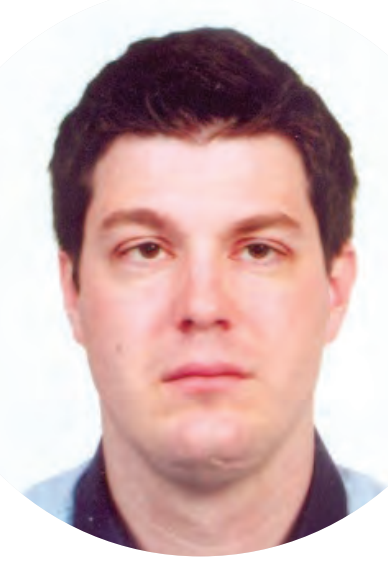

\section{Radoslav Barišić}

Radoslav Barišić has $\mathrm{PhD}$ and an MBA from the Faculty of Economics in Zagreb. He works in the Ministry of Regional Development and EU Funds, where he served as an advisor of the Minister for project financing. His current responsibilities are the development of Croatian islands and preparation of project financing from the EU funds. He is the author of a dozen scientific and professional papers. 